\title{
KARAKTERISASI RESERVOIR GAS BIOGENIK PADA LAPANGAN “TG” DENGAN MENGGUNAKAN ATRIBUT INVERSI IA DAN DEKOMPOSISI SPEKTRAL
}

\author{
Natassa Adi Putri ${ }^{1}$, Dwa Desa Warnana ${ }^{1)}$, Priatin Hadi Wijaya ${ }^{2)}$ \\ 1) Jurusan Teknik Geofisika FTSP ITS, ${ }^{2)}$ Puslitbang Geologi Kelautan \\ e-mail: nasaelric@gmail.com
}

\begin{abstract}
Abstrak. Gas Biogenik merupakan gas yang relatif dangkal terbentuk pada ekosistem lautan yang dangkal. Telah banyak ditemukan hidrokarbon dengan jenis gas biogenik di Indonesia, salah satunya adalah di Lapangan "TG". Oleh karena itu, dibutuhkan karakterisasi reservoir pada lapangan ini untuk memvalidasi keterdapatan hidrokarbon dan mengetahui reservoir dari lapangan tersebut. Metode yang digunakan adalah metode inversi seismik model based dengan parameter hard constraint untuk mengetahui properti fisik dari reservoir Lapangan "TG" dan dekomposisi spektral dengan metode Continuous Wavelet Transform (CWT) untuk mengetahui akumulasi dari gas biogenik di reservoir tersebut. Inversi seismik kemudian dikorelasikan dengan porositas sehingga membentuk penampang porositas pada daerah yang menjadi ketertarikan studi (interest) dan memiliki indikasi keterdapatan gas biogenik. Didapatkan bahwa Impedansi Akustik tinggi yang menjadi daerah interest merupakan reservoir karbonat dengan IA bernilai 4800-5300 (m/s)* (g/cc) dan dominan frekuensi pada frekuensi $16 \mathrm{~Hz}$.
\end{abstract}

Kata Kunci: dekomposisi spektral; gas biogenik; inversi impedansi akustik; porositas

\begin{abstract}
Biogenic gas is a shallow gas accumulation usually founded in shallow marine deposition. This gas occur mostly in the Northern part of Java Island one of them is in "TG" field. Therefore, reservoir characterization in this field for validating hydrocarbon indicator is prominent. Seismic Acoustic Impedance Inversion model-based is one of the method to validate the hydrocarbon using hard constraint parameter. This method allow us to describe physical properties from seismic record. This property can lead us to correlate with porosity to estimate porosity distrbution using linear regression. Moreover, this study using spectral decomposition method to identify gas accumulation in biogenic reservoir. By using Continuous Wavelet Transform to identify high frequency anomaly with Morlet wavelet parameter. The result shows interest zone study equivalent to $4800-5300(\mathrm{~m} / \mathrm{s})^{*}(\mathrm{~g} / \mathrm{cc})$ and dominant frequency in $16 \mathrm{~Hz}$.
\end{abstract}

Keyword : biogenic gas; model based inversion; porosity; spectral decomposition

\section{PENDAHULUAN}

Potensi gas biogenik di Indonesia yang cukup besar dan menjanjikan memberikan salah satu solusi sebagai pengganti energi konvensional. Penelitian yang dilakukan oleh Puslitbang Geologi Kelautan menunjukkan indikasi keterdapatan gas biogenik di sepanjang pantai utara Jawa pada tahun 2008. Pemetaan ini menghasilkan potensi sumber gas biogenik pada sedimen Holosen dengan menggunakan seismik pantul dangkal. Sama halnya dengan reservoir yang ditinjau pada Lapangan "TG". Lokasi studi pada penelitian ini adalah di Lapangan "TG" berada di perairan utara Jawa tepatnya di Cekungan Jawa Timur Utara. Reservoir pada Lapangan "TG" diperkirakan berada pada umur Pliosen-Plistosen, sehingga dibutuhkan metode interpretasi seismik untuk mengetahui karakter fisik dari reservoir ini.

Tujuan dari metode studi ini adalah untuk mengekstrak informasi fisik reservoir yang terdapat pada data seismik secara maksimal. Salah satu metode analisis ini dapat dicapai dengan menggunakan inversi dari data seismik serta dekomposisi spektral. Tujuan dari studi ini adalah menganalisis atribut inversi seismik impedansi akustik (IA) dan dekomposisi spektral berbasis metode Continuous Wavelet Transform dapat memberikan karakter fisik pada reservoir gas biogenik di Lapangan "TG".

Gas biogenik di Lapangan "TG" memiliki peran bakteri Globigerina dalam pembentukannya. Seperti yang diketahui, karena berumur PliosenPleistosen maka formasi ini memiliki kedalaman 
yang relatif dangkal dan masih masuk ke dalam zona neritik. Padahal, Globigerina sendiri merupakan foram laut dalam sehingga awal mula bakteri ini adalah pada bagian timur dari embayment yang disebutkan di atas. Dengan pengetahuan paleo-oseanografi dapat diketahui bahwa sepanjang umur Pliosen, terdapat pola arus ke arah barat dari Kangean menuju Cepu pada embayment tersebut. Kemudian terjadi upwelling currents yang membawa foram Globigerina di wilayah laut dalam (abyssal) naik ke wilayah yang lebih dangkal (neritik). Tempat tersebut kemudian mengalami deposisi dan reworking yang disebabkan karena badai. Hal ini dibuktikan dari hasil coring yang dilakukan oleh Santos pada Lapangan "TG" memiliki pola seperti tunjaman dan permukaan yang tererosi yang menunjukkan bahwa hal tersebut adalah hasil dari reworking pada wilayah neritik. Pembentukan dari gas biogenik ini berdasarkan pembentukan hidrokarbon yang disebabkan oleh makhluk hidup (biogenik) (Satyana, 2006).

Metode inversi model based merupakan metode inversi yang menggunakan prinsip konvolusi dari tras seismik. Inversi ini membutuhkan model awal untuk mendapatkan data seismogram sintetik sebagai bagian dari algoritmanya. Tras seismik, wavelet, dan noise tidak beraturan dan tidak berkorelasi dengan sinyal. Metode inversi ini memecahkan masalah di atas dengan cara mencari reflektifitas secara iteratif dengan membandingkan perbedaan antara tras seismik yang sebenarnya dengan sintetik seismogram yang didapatkan pada model awal dengan beberapa batasan dan kompensasi yang dapat diatur pada model awal. Berikut adalah algoritma yang digunakan dalam inversi tersebut:

$$
r=\left(W^{T} W+\lambda I\right)^{-1} W^{T} T
$$

dengan:

$r \quad=$ reflektifitas hasil impedansi,

$\mathrm{W} \quad$ = fungsi wavelet,

$\lambda=$ faktor prewhitening,

I = matriks identitas,

$\mathrm{T} \quad$ = tras seismik. (Russell, 1999).
Dekomposisi Spektral merupakan proses penguraian spektrum frekuensi yang terdapat pada data seismik. Dasar dari proses ini adalah transformasi domain data seismik ke dalam domain frekuensi dengan menggunakan metode STFT atau CWT dimana metode CWT memberikan solusi yang lebih akurat dibandingkan STFT. Metode CWT memberikan window time-frequency yang secara otomatis mengecil ketika mengobservasi frekuensi tinggi dan membesar ketika mengobservasi frekuensi rendah. Metode ini menggunakan dilatasi dan translasi untuk menghasilkan peta skala-waktu. Dalam persamaan CWT didefinisikan sebagai berikut:

$W_{x}(u, s)=\int_{-\infty}^{+\infty} X(t) \Psi_{u, s}^{*}(t) d t$

dengan fungsi inverse transformasi wavelet adalah

$x(t)=\frac{1}{C_{\psi}} \int_{0}^{-\infty} \int_{-\infty}^{+\infty} W_{x}(u, s) \Psi_{u, s}(t) d u \frac{d s}{s^{2}}$

dengan:

$C_{\Psi}$ disebut sebagai kondisi diterima (admissibility conditions)

u merupakan parameter translasi, s merupakan parameter skala, dan $\Psi$ konjugasi merupaka induk wavelet (Haryono, (2012).

\section{METODOLOGI}

Gambar 1 menunjukkan diagram alir proses yang dilakukan dalam studi ini. Hal yang pertama dilakukan adalah persiapan data untuk melihat kelengkapan data.

Penentuan daerah interest dilakukan dengan melakukan analisis log secara kualitatif. Proses ini dinamakan dengan Well Log Quicklook dimana dilakukan deskripsi awal terhadap daerah interest dengan mengidentifikasi karakter fisiknya. Dalam studi ini, reservoir yang menjadi target adalah reservoir karbonat dengan rentang kecepatan adalah $4500-5500(\mathrm{~m} / \mathrm{s})^{*}(\mathrm{~g} / \mathrm{cc})$ dengan porositas sangat baik yaitu $30 \%-40 \%$. Parameter porositas didapatkan dari informasi geologi yang didapatkan dari instansi terkait sedangkan parameter kecepatan didapatkan dari referensi mengenai karbonat Pliosen-Plistosen pada Lapangan "TG". 


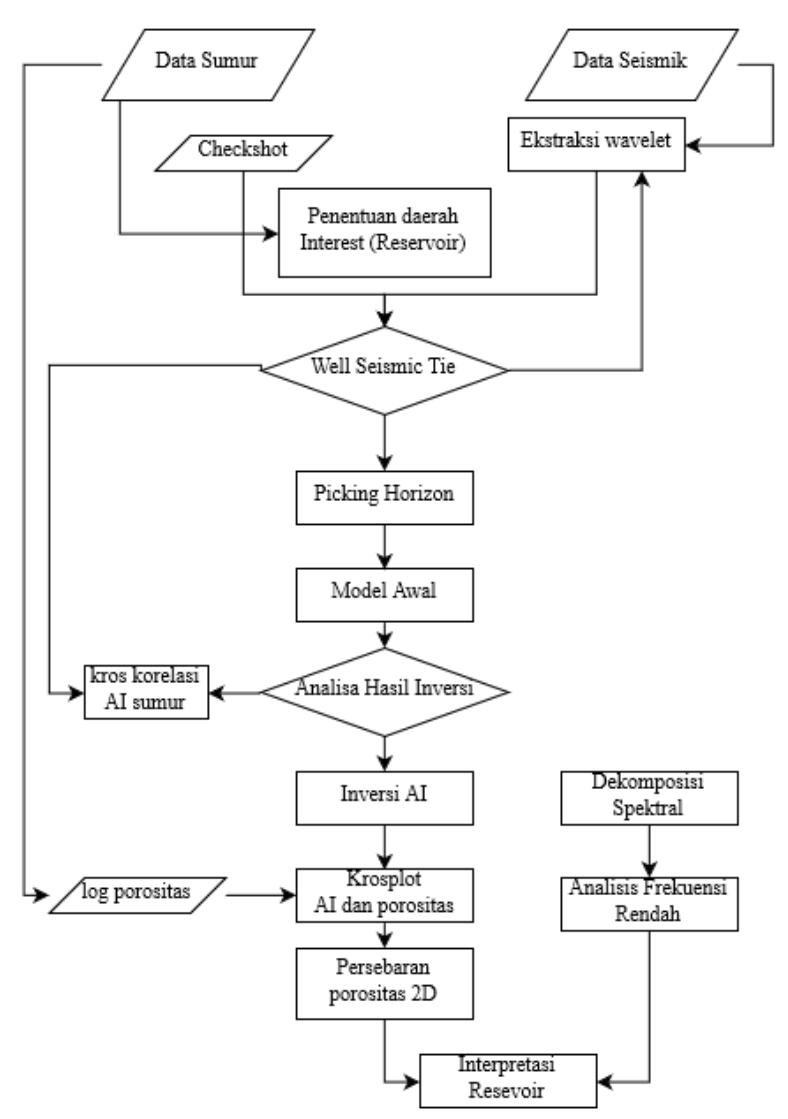

Gambar 1. Diagram Alir Pada Penelitian Yang Dilakukan.

Proses awal dari inversi seismik adalah melakukan pengikatan sumur pada data seismik. Terdapat dua sumur yang diikatkan yaitu sumur TG1 dan TG2-ST pada data seismik TG3-9. Inversi dilakukan dengan analisis kelayakan inversi dimana pada tahap ini dilakukan penentuan model awal dari batas yang telah ditentukan kemudian dihitung errornya. Model yang digunakan adalah model yang memiliki error yang paling kecil dan kemiripan geologi yang paling sesuai. Pada pembuatan peta porositas digunakan crossplot antara log porositas (dihitung dengan menggunakan log densitas yang dibatasi pada daerah interest) dan hasil inversi IA dari seismik. Proses ini dilakukan untuk mencari hubungan antara parameter keduanya untuk membuat penampang porositas.

Proses dekomposisi spektral dilakukan setelah data seismik yang akan digunakan difilter frekuensi dengan filter bandpass (4-13-50-60). Metode yang digunakan adalah berbasi CWT (Continuous Wavelet Transform) untuk melihat daerah akumulasi gas yang terdapat pada reservoir di Lapangan "TG". Karena kasus pada studi ini adalah batuan karbonat dengan kandungan gas, maka dilakukan analisis frekuensi rendah dan tinggi secara bersamaan.

Dari keseluruhan proses yang dilakukan, hal selanjutnya adalah melakukan interpretasi reservoir dengan melakukan crossplot antara Porositas Impedansi P dan Impedansi P - Gamma Ray yang berasal dari data sumur untuk melihat posisi reservoir gas.

\section{HASIL DAN PEMBAHASAN}

\section{Analisis Daerah Interest (Data Log)}

Pada daerah interest yang ditentukan pada kedalaman 884-1036 meter, kemudian dilakukan indikasi reservoir gas biogenik dilihat dari karakteristik litologi yang didapatkan dari informasi log pada Gambar 2; Log Gamma ray, saturasi air dan resistivitas. Ketiga kombinasi log tersebut dapat menunjukkan kandungan hidrokarbon dalam hal ini adalah gas biogenik. Pada daerah yang dibatasi oleh kotak merah, log gamma ray menunjukkan nilai yang kecil dengan kisaran 30-40 API yang menunjukkan bahwa litologi tersebut adalah limestone. Selain itu, pada daerah tersebut nilai saturasi air menurun hampir mencapai 0 menunjukkan bahwa tidak ada kandungan air di dalam daerah tersebut. Kombinasi antara log neutron dan densitas dapat digunakan pula untuk mendeteksi keberadaan gas. Gambar 2 menunjukkan log neutron dan densitas pada kolom ke 6. Pola dari kombinasi antara log porositas dan densitas ini memberikan pola crossover dimana keduanya akan saling berbanding terbalik. Magnitudo dari pola crossover ini tergantung secara kualitatif berhubungan dengan kandungan gas yang terdapat dalam formasi. Semakin banyak gas yang terdapat dalam suatu formasi, maka magnitude yang dihasilkan akan semakin lebar. 


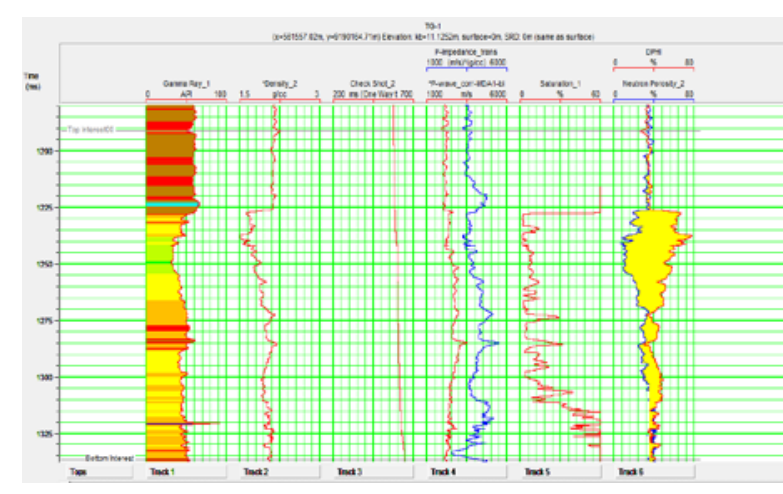

Gambar 2. Hasil Log Quick Look.

\section{Analisis Daerah Interest (Data Seismik)}

Untuk mengidentifikasi daerah interest pada data seismik, tahap yang pertama dilakukan adalah mencari anomali yang dapat diindikasikan sebagai reservoir gas biogenik. Gambar 3 merupakan data seismik pada lintasan TG3-9. Ditemukan beberapa anomali yang berasosiasi dengan keberadaan reservoir karbonat dan gas biogenik. Lingkaran kuning menunjukkan adanya Direct Hydrocarbon Indicator (DHI) berupa brightspot. DHI ini disebabkan karena kecepatan dari batuan karbonat yang tinggi berasosiasi dengan gas yang memiliki kecepatan lebih rendah sehingga koefisien refleksi akan menjadi positif. Kecepatan gelombang seismik akan terabsorbsi pada lapisan gas sehingga menghasilkan akumulasi energi seismik yang ditunjukkan dari tingginya amplitudo. Hal ini kemudian berasosiasi dengan refleksi acak (chaotic) yang berada di atas DHI. Anomali ini menunjukkan bahwa reservoir karbonat bersifat porous dan memiliki nilai impedansi yang tinggi. Sehingga, gelombang seismik yang melewati lapisan tersebut terekam sangat cepat dan memberikan penampang yang acak (hampir tidak ada refleksi).

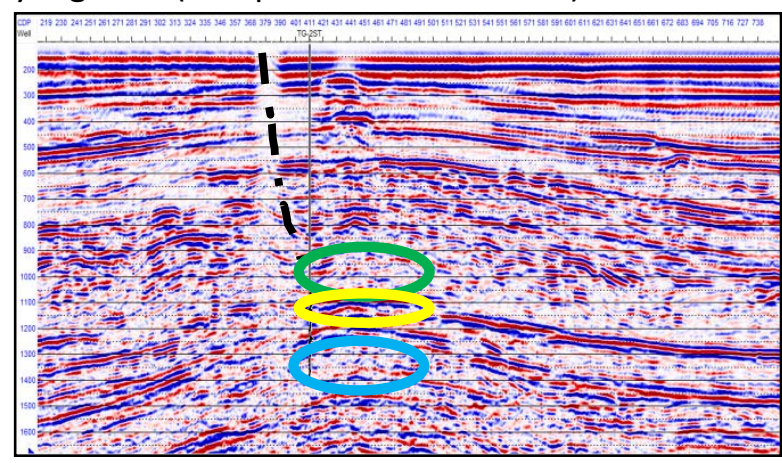

Gambar 3. Hasil Seismic Quick Look.
Hal berbeda terjadi pada lingkaran biru muda pada Gambar 3 yang memiliki refleksi acak seperti refleksi yang terdapat pada lingkaran hijau. Anomali ini disebabkan karena efek gas dangkal yang terdapat pada reservoir. Anomali brightspot menjadi tempat absorbsi energi gelombang yang cukup besar sehingga akan menurunkan energi awal gelombang seismik.

\section{Seismic Well Tie}

Dalam tahap ini hal yang paling penting adalah proses ekstraksi wavelet. Ekstraksi dilakukan dengan menggunakan metode dekonvolusi pada data seismik yang dikenal dengan metode ekstraksi statistical. Hal ini dilakukan untuk meningkatkan korelasi yang baik antara data seismik dengan data sumur. Selanjutnya dilakukan shifting dan stretching untuk mencocokkan antara event refleksi seismik dengan sintetik seismogram yang didekati dari sumur. Korelasi yang didapatkan dari sumur TG-1 adalah 0.763 dan sumur TG-2ST adalah 0.753.

\section{Analisis Kelayakan Inversi}

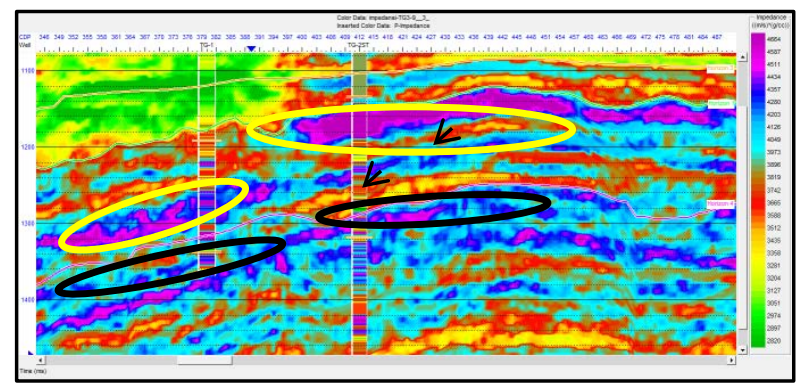

Gambar 4 Hasil Inversi Impedansi.

Pada Gambar 4, dapat dilihat pada lingkaran berwarna kuning dan hitam. Lingkaran kuning diinterpretasikan sebagai batas atas dari reservoir karbonat dengan nilai impedansi sebesar 4700$5300\left((\mathrm{~m} / \mathrm{s})^{*}(\mathrm{~g} / \mathrm{cc})\right)$. Sedangkan pada lingkaran hitam diinterpretasikan sebagai batas bawah dari reservoir karbonat dengan nilai impedansi sebesar 4500-5000 ((m/s)*(g/cc)). Kemudian pada tanda panah di antara kedua lingkaran tersebut terdapat nilai impedansi yang lebih rendah dengan nilai sekitar $3500-3800((\mathrm{~m} / \mathrm{s}) *(\mathrm{~g} / \mathrm{cc}))$ ditunjukkan dengan warna kuning sampai oranye. Hal ini dapat 
diinterpretasikan sebagai kandungan gas dimana saat gelombang seismik melewati reservoir gas maka akan terjadi penyerapan energi sehingga kecepatan gelombang akan melambat. Impedansi akustik merupakan fungsi dari densitas dan kecepatan. Dari kedua fungsi tersebut kecepatan lebih banyak mempengaruhi perubahan dari impedansi dikarenakan nilai densitas antar batuan yang tidak jauh berbeda. Sedangkan nilai impedansi memiliki jarak yang jauh untuk tiap satu jenis batuannya. Oleh karena itu, dapat diinterpretasikan bahwa tanda panah pada Gambar 4 dapat diinterpretasikan sebagai kandungan hidrokarbon.

\section{Pembuatan Penampang Porositas}

Setelah proses korelasi dan interpretasi pada penampang impedansi dilakukan, proses selanjutnya adalah menentukan crossplot antara impedansi hasil inversi dengan hasil transformasi log porositas dengan pendekatan log densitas dan resistivitas.

Persamaannya:

$$
y=-0.000123705 x+0.944
$$

Dari persamaan (4) kemudian dimasukkan ke dalam kalkulasi penampang IA yang telah diinversi menggunakan fasilitas pada perangkat 1 , sehingga didapatkan penampang porositas sebagai berikut:

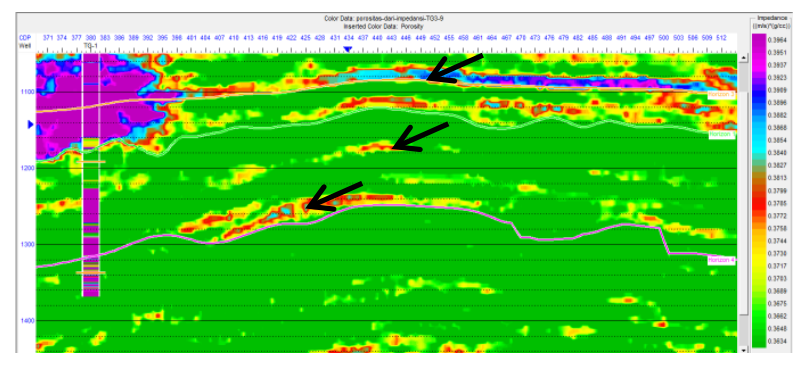

Gambar 5. Penampang Porositas Hasil Kalkulasi Persamaan Linear 4.

Gambar 5 menampilkan nilai persebaran porositas yang didapatkan dari persamaan 4 dan didapatkan beberapa anomali yang ditunjukkan dengan tanda panah. Pada tanda panah menunjukkan nilai porositas yang cukup tinggi di daerah antara batas atas dan batas bawah yang diinterpretasikan. Hal ini berasosiasi dengan kandungan gas yang terdapat pada reservoir tersebut sehingga keberadaan hidrokarbon pada reservoir ini semakin terbukti. Nilai porositas yang ditampilkan pada penampang tersebut adalah 0.37 0.5 .

\section{Dekomposisi Spektral}

Sebelum dilakukan ekstraksi frekuensi, dapat dilihat penampang seismik TG3-9 walaupun sudah dilakukan conditioning data, masih terlihat beberapa daerah yang chaotic ditandai dengan lingkaran hitam. Hal ini dapat disebabkan karena efek dari gas dangkal yang terdapat di dekat permukaan.

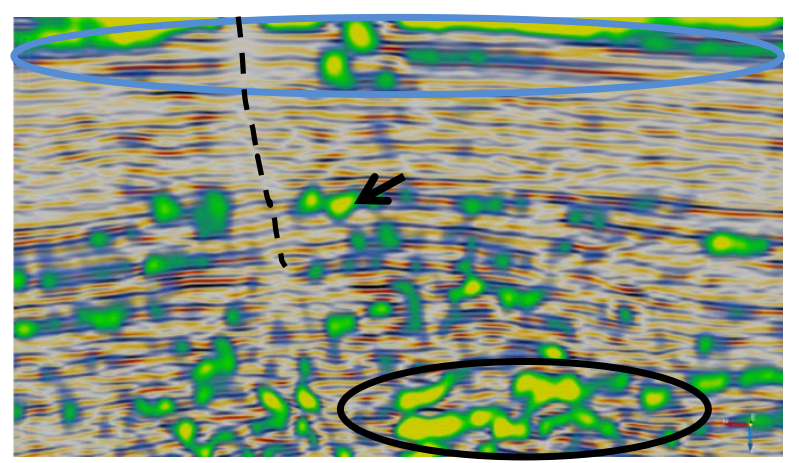

Gambar 6. Penampang Isofrekuensi $13 \mathrm{~Hz}$.

Dapat dilihat di penampang isofrekuensi $13 \mathrm{~Hz}$ pada Gambar 6 keterdapatan anomali frekuensi rendah terlihat pada tanda panah berwana hitam. Penampang ini mengindikasikan keterdapatan akumulasi gas pada daerah top reservoir. Lingkaran biru menunjukkan nilai frekuensi rendah yang terdapat pada penampang dekat permukaan. Hal ini menunjukkan keterdapatan noise dari data seismik. Lingkaran hitam yang terdapat pada penampang menunjukkan daerah dengan frekuensi rendah yang disebabkan karena penyerapan energi yang besar terjadi pada daerah atasnya (daerah reservoir gas). 


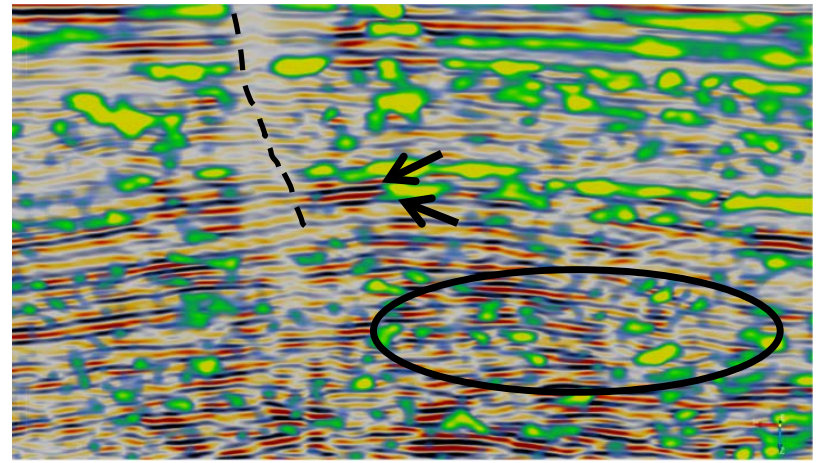

Gambar 7. Penampang Isofrekuensi $40 \mathrm{~Hz}$.

Penampang isofrekuensi $40 \mathrm{~Hz}$ pada Gambar 7 mengindikasikan keterdapatan akumulasi gas lebih baik pada batas atas dan bawah reservoir. Pada bagian bawah bottom reservoir sudah tidak seterang seperti kedua penampang sebelumnya. Pada penampang ini, lapisan tipis lainnya yang tidak teridentifikasi pada isofrekuensi $16 \mathrm{~Hz}$ dan $13 \mathrm{~Hz}$ terdeteksi dengan jelas memanjang ke bagian kanan dari top dan bottom reservoir. Lingkaran hitam menunjukkan bahwa frekuensi tinggi tidak terdapat pada daerah tersebut. Hal ini semakin menunjukkan lokasi reservoir dari penampang seismik TG3-9.

\section{Analisis Crossplot}

\section{Crossplot Gamma Ray dan Impedansi-P}

Berikut adalah analisis dari crossplot di antara dua variabel tersebut.

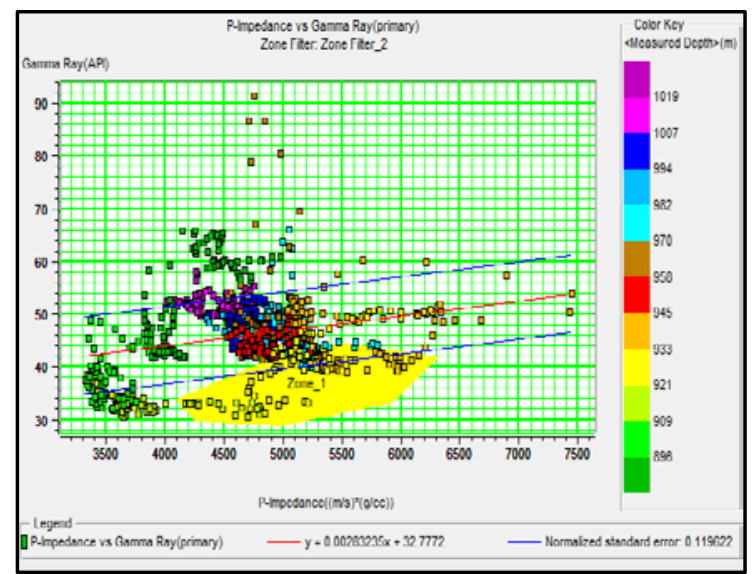

Gambar 8. Crossplot antara Impedansi P dan Gamma Ray pada Sumur TG-1.
Pada reservoir karbonat, nilai impedansi memiliki kisaran yang cukup tinggi dan pada reservoir Lapangan "TG", diketahui nilai rata-rata dari reservoir ini adalah $4800\left((\mathrm{~m} / \mathrm{s})^{*}(\mathrm{~g} / \mathrm{cc})\right)$. Selain itu reservoir ini memiliki nilai impedansi yang relatif kecil yaitu antara 30-40 API. Oleh karena itu, nilai tersebut dijadikan batas (cutoff) dalam penentuan daerah reservoir di sumur TG-1. Pada Gambar 8 terdapat poligon berwarna kuning yang diinterpretasikan sebagai daerah reservoir dari nilai batas yang didapatkan.

\section{Crossplot Impedansi P dan Porositas Sumur}

Berikut adalah crossplot antara kedua variabel tersebut.

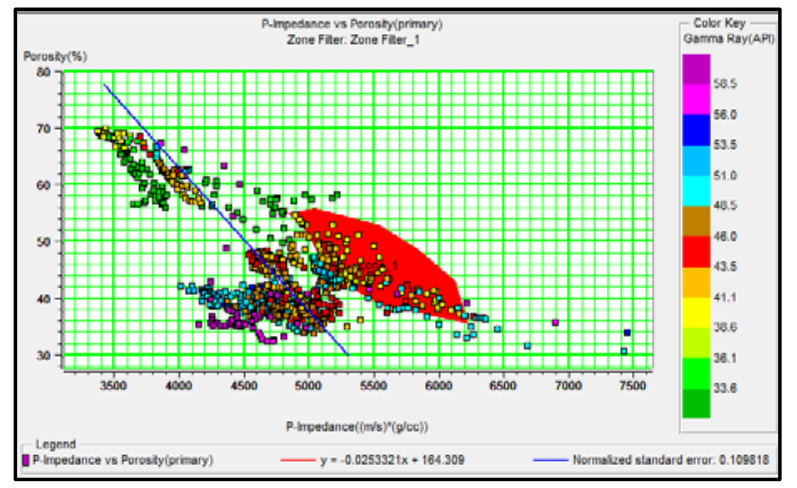

Gambar 9 Crossplot antara Impedansi P dan Porositas Sumur TG-1.

Gambar 9 menunjukkan hubungan antara impedansi sumur dan porositas. Terlihat pada gambar tersebut bahwa nilai porositas dan nilai impedansi akustik saling berbanding terbalik. Hal ini dapat dijadikan dasar untuk penentuan daerah reservoir. karakter dari reservoir yang diinterpretasikan adalah batuan karbonat yang memiliki nilai impedansi $P$ yang tinggi. Pada analisis tuning thickness di atas, nilai kecepatan rata-rata reservoir adalah $4800\left((\mathrm{~m} / \mathrm{s})^{*}(\mathrm{~g} / \mathrm{cc})\right)$, sedangkan dalam penentuan porositas reservoir digunakan cutoff sebesar 30\%-40\% dan memilki nilai Gamma ray yang rendah yaitu 30-40 API. 


\section{KESIMPULAN}

Dari studi ini kesimpulan yang dapat diambil adalah:

1. Proses karakterisasi reservoir pada gas biogenik dengan kasus litologi karbonat membutuhkan data yang lengkap dan baik untuk mengurangi ketidakpastian dikarenakan karakter fisik dari karbonat tersaturasi gas yang begitu kompleks.

2. Metode dekomposisi spektral berbasis Continous Wavelet Transform dapat memberikan gambaran pada daerah akumulasi gas. Dengan kasus seperti reservoir karbonat, anomali frekuensi tinggi menjadi lebih baik digunakan dibandingkan anomali frekuensi rendah yang selama ini digunakan.

3. Impedansi yang tinggi dari karbonat memberikan keuntungan pada karakterisasi dengan menggunakan inversi impedansi akustik.

4. Proses ekstraksi karakter fisik data seismik dapat membuktikan bahwa reservoir gas biogenik dapat diidentifikasikan dengan nilai impedansi sebesar $4800-5300(\mathrm{~m} / \mathrm{s})^{*}(\mathrm{~g} / \mathrm{cc})$ dengan nilai porositas yang sangat baik dengan nilai 0.370.39 berada pada kedalaman $920-980 \mathrm{~m}$.

\section{SARAN}

Saran yang dapat diambil dari studi ini adalah:

1. Perlu adanya re-processing pada data yang bersangkutan untuk menghilangkan noise di dekat permukaan karena efek gas dangkal. Sehingga akan memberikan gambaran yang baik pada setiap metode.

2. Studi mengenai reservoir karbonat Globigerina ini masih cukup jarang ditemui, oleh karena itu, diperlukan informasi yang lebih banyak untuk proses pembentukan dan sedimentasi dari reservoir ini.

3. Dibutuhkan data yang lebih banyak dan lengkap dalam penelitian ini untuk mengekstrak karakter fisik batuan dari data seismik seperti misalnya data pre-stack untuk analisis AVO.

\section{UCAPAN TERIMA KASIH}

Penulis mengucapkan terima kasih kepada instansi Pusat Penelitian dan Pengembangan Geologi Kelautan atas data dan bimbingan yang telah diberikan dalam pelaksanaan penelitian ini.

\section{DAFTAR PUSTAKA}

Burnett, M. D., 2003. Application of Spectral Decomposition to Gas Basins in Mexico. The Leading Edge, 1130-1134.

Castagna, J. P., 2003. Instantaneous Spectral Analysis: Detection of Low Frequency Shadows Associated with Hydrocarbon. The Leading Edge, 120-127.

Dudley D Rice, D. C. (1981). Generation, Accumuklation and Resource Potential of Biogenic Gas. The American Association of Petroleum Geologist.

Febryanto, I., 2014, Agustus 27. Scribd.com. Retrieved Desember 31, 2015, from www.scribd.com

Haryono, 2012. Evaluasi Prospek Lapangan XYZ Berdasarkan Atribut Inversi Seismik dan Dekomposisi Spektral. Depok: Thesis Universitas Indonesia.

Ir. Yudi Darlan, M. d., 2005. Eksplorasi Prospektif Gas Biogenik Kelautan Perairan Muara Kakap dan Sekitarnya - Kalimantan Barat. Bandung: Pusat Penelitian dan Pengembangan Geologi Kelautan.

J.P. Castagna, H.W. Swan, and Foster., 1998. Framework for AVO Gradient and Intercept Interpretation. Geophysics 63, 948-956.

Kelautan, P. G., 2004. Gas Biogenik Sumber Energi Alternatif. Retrieved 2016, from esdm.go.id: www.esdm.go.id

Korneev, V. A., 2004. Seismic Low Frequency Effect in Monitoring Fluid Saturated reservoirs. Geophysics Vol.69 No.2, 522-532.

Mavko, G. T., 2009. The Rock Physics Handbook. Cambridge, UK: Cambridge University Press.

Missiaen T. S. Murphy, L. L., 2000. Very High Resolution Seismic Mapping of Shallow Gas in The Belgian Coastal Zone. Pergamon - Continental Shelf Research 22 (2002), 2291-2301.

Oktavia, C. W., 2010. Analisa Karakterisasi Reservoir Batugamping Berdasarkan Seismik Inversi Untuk Memetakan Porositas Reservoir Batugamping Pada Formasi Baturaja Lapangan "SUN". Surabaya: Jurusan FMIPA ITS. 
Partyka, G. G., 1999. Interpretation Application of Spectral Decomposition in Reservoir Characterization. The Leading Edge, 353-360.

Per Avseth, T. M., 2005. Quantitative Seismic Interpretation. United Kingdom: Cambridge University Press.

Russell, B., 1988. Introduction to Seismic Inversion Methods. Calgary: Society of Expploration Geopysicist.

Russell, H. a., 1999. Theory of Strata Program. Houstoun: CGGveritas.

Satyana, A., 2006, Maret Senin, 27. iagi-net. Retrieved Mei Selasa, 2016, from iagi.or.id: iagi.or.id

SEPM, S., 2016. SEPM Strata. Retrieved May 2016, from SEPM Stratigraphy Web: www.sepmstrata.or

Sukmono, S., 2000. Seismik Inversi Untuk Karakterisasi Resevoir. Bandung: Jurusan Teknik Geofisika ITB.

Susilohadi, 1995. Late Tertiary and Quaternary Geology of The East Java Basin, Indonesia. Australia: The University of Wolonggong.

Troa, R. A., 2009. Analisis Indikasi Hidrokarbon di Cekungan Busur Muka Lombok Dengan Menggunakan Data Seismik Refleksi Multichannel 2D. Depok: Thesis Universitas Indonesia.

Wibisono, E., 2009. Analisis dan Inversi AVO SImultaneous Untuk Mengekstrak Sifat Fisika Batuan: Studi Kasus Batupasir Formasi Gumai Pada Sub Cekungan Jambi. Depok: Skripsi Universitas Indonesia.

Yangdong Li, dkk., 2011. High Frequency Anomalies in Carbonate Reservoir Characterization Using Spectral decomposition. Geophysics, 47-57.

Yanyan Triyana, Gregory I. Harris, Ed Tadiar, Neil C. Sharp., 2007. The Maleo Field: An Example of The Pliocene Globigerina Bioclastic Limestone Play in The East Java Basin - Indonesia. 31st Indonesian Petroleum Association (pp. 45-61). Jakarta: IPA. 